\title{
Comparative Analysis of Signal Strength of Some Cellular Networks in Port Harcourt, Nigeria.
}

\author{
B.I. Bakare, T. E. Ngeri and Sunny Orike
}

\begin{abstract}
This paper presents a comparative analysis of the Received Signal Strength (RSS) measurement of some cellular networks in Port Harcourt, Nigeria. Measurements were carried out using Radio Frequency Signal Tracker to determine received signal of three selected Global System for Mobile Communication networks (MTN, Airtel and Globalcom) at five strategic locations (Borokiri, Old Government Residential Area, Rivers State University, Ikwerre Road and Aba Road) in Port Harcourt, Rivers State. From the results obtained it shows that in Borokiri MTN has the highest received signal strength of 61.9dBm, Old GRA Airtel has the highest received signal strength of $-61.3 \mathrm{dBm}$, RSU and Ikwerre Road Globalcom has the highest received signal strength of $-68.3 \mathrm{dBm}$ and $-64.9 \mathrm{dBm}$ respectively while for Aba Road MTN has the highest received signal strength of $-63.0 \mathrm{dBm}$. In all the measurements, the results were analyzed using least square method and standard deviation to approximate the measurement data and path loss model was developed using ordinary least square regression technique.
\end{abstract}

Index Terms-Attenuation; Signal Tracker; Received Signal Strength, Transmitter.

\section{INTRODUCTION}

The wireless telephone system which is a major breakthrough in Communication comes either in fixed wireless lines or the Global System for Mobile communication (GSM) [1]. Statistics have shown that in many countries the use of mobile phone is already higher than the fixed one [2] and [3].Communication is a major driver of any economy. Nigeria is not left out in the race of rapid development. However with the advent of GSM in Nigeria, telecommunication services have been brought closer to individuals in the country [4]. GSM has its own challenges in the area of signal reception.

GSM network in Nigeria is currently faced with the challenge of subscriber's dissatisfaction in the quality of services offered by the existing network providers. In this research work, the signal strength of some cellular networks (MTN, Globalcom and Airtel) operational in Port Harcourt were measured and compared to ascertain the network with better signal strength. The Signal strength measurement was carried out using Radio Frequency Signal Tracker.

The measurements were conducted at five strategic locations (Borokiri, Old Government Residential Area, Aba Road,

B.I.Bakare is with the Electrical Engineering Department, Rivers State University, Port Harcourt. Nigeria (e-mail: bakare.bodunrin@ust.edu.ng)

T. E. Ngeri is with the Electrical Engineering Department, Rivers State University Port Harcourt, Rivers State, Nigeria
Ikwerre Road, and Rivers State University). Three networks (MTN, Globalcom and Airtel) were considered to determine the cellular network with the best received signal strength using Radio Frequency Signal Tracker (RFST).

The locations were chosen randomly based on the size of population. Borokiri lies between latitude $4^{\circ} 47^{\prime} 24^{\prime \prime}$ North of the Equator and longitude $7^{\circ} 2^{\prime} 6$ " East of the Greenwich Meridian line. Old Government Residential Area lies between latitude $4^{\circ} 47^{\prime} 3.48^{\prime}$ North of the Equator and longitude $7^{\circ} 0$ '34.44" East of the Greenwich Meridian line, Aba Road lies between latitude $4^{\circ} 49^{\prime} 4.44^{\prime \prime}$ North of the Equator and longitude $7^{\circ} 0{ }^{\prime} 37.44$ " East of the Greenwich Meridian line, Ikwerre Road lies between latitude 4'49'17.16" East of the Equator and longitude 6 59 '2.4" of the Greenwich Meridian line while Rivers State University (RSU) lies between latitude 4\% 49'34.68'North of the equator and longitude $6^{\circ} 58^{\prime} 52.32$ " East of the Greenwich Meridian line. Figure 1 shows the Google Earth Map of the locations of measurement

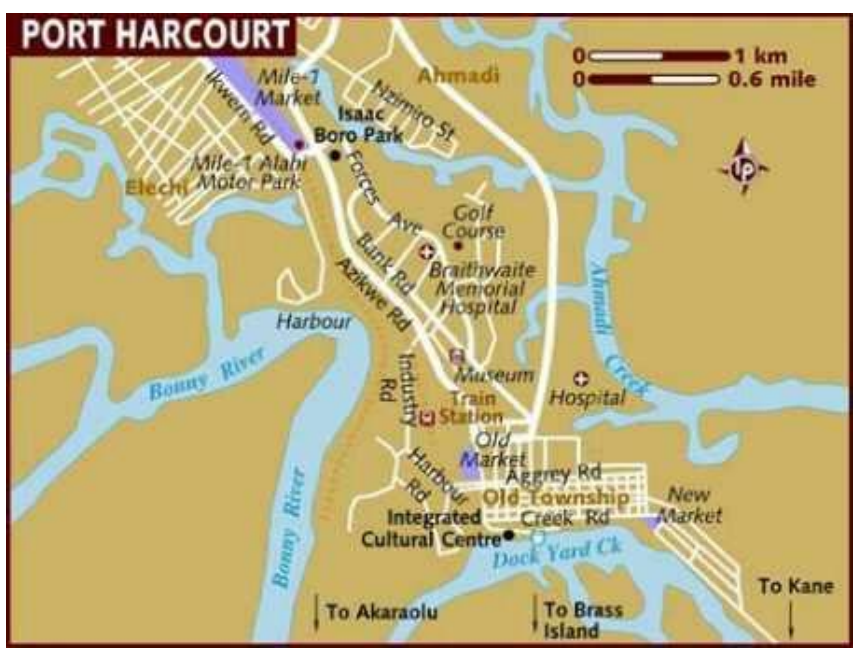

Fig. 1. Google Earth Map showing the Locations of Measurement

\section{PATH LOSS MODELS}

When making an estimation of the possibilities for a radio system to function, it is a common practice to set up a link budget [5]. Simplified models are used frequently due to short coming of making an accurate estimate of all the parameters

Sunny Orike is with the Electrical Engineering Department, Rivers State University Port Harcourt, Rivers State, Nigeria 
involved in the processing of the signal from the transmitter to the receiver.

The Frii's Free Space formula [5] is given as;

$P_{R}=\frac{P_{T} G_{T} G_{R}{ }^{2}}{L_{T} L_{R}(4 \pi d)^{2}}$

Where $P_{R}=$ Received power, $G_{R}=$ Receiver antenna gain, $G_{T}$ $=$ Transmitter antenna gain, $L_{R}=$ Receiver losses, $L_{T}=$ Transmitter losses, $\lambda=$ Signal wavelength, $d=$ Distance between the transmitter and the receiver antenna

There are many empirical propagation path loss models that are efficient and simple to use as it is obtained from indepth field measurement. Site specification models are based on numerical methods and finite difference time domain (FDTD) technique and for the theoretical propagation path loss models are obtained from physical hypothetical assumptions while the diffraction models is obtained by using physical optics with the assumption of constant height and building spacing [6]. These models include the Free Space Model, Hata Propagation Model, Stanford University Interim (SUI) Model, Longley- Rice Model, Electronic Communication Committee-33 (ECC-33) Model, Cooperative for Scientific Research (COST-231) Model, LEE Model, Regression Model, Least Square Formulation Model, Path Loss Exponent Model with Aggregate penetration Loss (APL), Partition-Based Out Door-In Door Model etc. This paper emphasized on the Free Space Model, ECC-33 Model, COST-231 and Hata Models [6].

\section{A. Free Space Propagation Path Loss Model}

This model assumes that there is no obstacle between the transmitter and the receiver during signal propagation. In this case the transmitter radiates signal to an infinite distance with a situation of signal absorption or reflection [6]. In a case where the transmitter propagates signal at 360 using a fixed power with an ever increasing sphere, the transmitter will have a power flux of;

$\mathrm{P}_{\mathrm{d}}=\frac{\mathrm{P}_{\mathrm{t}}}{4 \pi \mathrm{d}^{2}}$

Where $P_{\mathrm{t}}$ is the power of the transmitter and $\mathrm{P}_{\mathrm{d}}$ is the power obtained when the distance is from the antenna.

Free Space Propagation shows that the signal received by the receiver decays with distance between the transmitter and the receiver at a rate of $20 \mathrm{~dB} / \mathrm{dec}$ de. It is also between the transmitter and the receiver.

\section{B. ECC-33 Model}

This model stands for Electronic Communication Committee-33 model. This model extrapolates the Okumura measurements and amended its assumptions to closely depict a fixed wireless access system. This model is commonly suitable for Suburban small areas [6]. The equation for this model is given as;

$\mathrm{PL}=\mathrm{PL}_{\mathrm{F} 3}+\mathrm{PL}_{\mathrm{bm}}-\mathrm{G}_{\mathrm{b}}-\mathrm{G}_{\mathrm{m}}$

Where $\mathrm{PL}_{\mathrm{f} 3}$ is the free space path loss given as:

$\mathrm{PL}_{\mathrm{F} 3}=92.4+20 \log _{10}(\mathrm{~d})+20 \log _{10}(\mathrm{f})$

$\mathrm{PL}_{\mathrm{bm}}$ is the basic median path loss given as;

$\mathrm{PL}_{\mathrm{bm}}=20.41+9.83 \log _{10}(\mathrm{~d})+7.994 \log _{10}(\mathrm{f})+$

9.56( $\left.\log _{10}(\mathrm{f})\right)^{2}$

$\mathrm{F}$ is the frequency in MHZ and $\mathrm{d}$ is the distance between the transmitter and the receiver in $\mathrm{Km}$.

$$
\begin{aligned}
& G_{b}=\log _{10}\left(\frac{h b}{200}\right)\left\{13.98+5.8\left[\log _{10}(d)\right]^{2}\right\} \\
& G_{\mathrm{m}}=\left[42.57+13.7 \log _{10}(\mathrm{f})\right]\left[\log _{10}(\mathrm{hm})-0.585\right](7)
\end{aligned}
$$

\section{COST-231 Propagation Model}

This model stands for co-operative for Scientific and Technical Research. It is an enhanced version of the Hata Propagation Model. It uses four variables in predicting propagation loss which includes frequency, height of base station antenna, height of receiving antenna and distance between base stations and receiving antenna. The path loss equation for COST-231 propagation model is given as; $\mathrm{PL}(\mathrm{db})=46.3+33.9 \log _{10}(\mathrm{fc})-13.82 \log _{10}(\mathrm{hb})-$ $\mathrm{a}(\mathrm{hm})+\left(44.9-6.5-\operatorname{SLog}_{10}(\mathrm{hb})\right) \log _{10}(\mathrm{~d})+\mathrm{CM}$

Where CM may be 0 for Suburban City or 3 for Metropolitan City

\section{Hata Propagation Model}

This is a set of equation obtained on measurements and extrapolations taken from curves derived by Okumura. It is fully empirical prediction method formulated for graphical path loss. The model is appropriate for frequency range of 150MHZ-1500MHZ (UHF) and for distance of $1 \mathrm{Km}-20 \mathrm{Km}$. The model does not consider terrain profiles like hills that are found between the transmitter and the receiver. Three cases are used to calculate path loss associated with this model [6].

Case 1: Urban Hata Path Loss

$\mathrm{PL}=69.55+26.16 \log _{10}(\mathrm{fc})-13.82 \log _{10}(\mathrm{hb})+(44.9$

$\left.6.55 \log _{10}(\mathrm{~d})+\mathrm{MS}-\mathrm{a}(\mathrm{hm})\right)$

Case 2:Suburban Hata Path Loss

$\mathrm{PL}=$ PLUrban $-2\left(\left(\log _{10} \frac{\mathrm{fc}}{28}\right)\right)^{2}-5.4$

Case 3:Rural Hata Path Loss

$P L=$ PLUrban $-4.78\left(\left(\log _{10}(f c)^{2} \quad\right) \quad+18.33\right.$

$\log _{10}(f c)-40.98$

Where MS is the Mobile Station antenna correction factor $\mathrm{a}(\mathrm{hm})=1.11 \log (\mathrm{fc})-0.7 \mathrm{hm}(1.56 \log (\mathrm{fc})-0.5)(\mathrm{dB})$

Where hb is the transmitter height, $\mathrm{hm}$ is the receiver height and $\mathrm{fc}$ is the transmitting frequency.

\section{MATERIALS AND METHODS}

\section{A. Measurements}

Signal Strength measurements were conducted at five strategic locations (Borokiri, Old Government Residential Area, Aba Road, Ikwerre Road, and Rivers State University) in Port Harcourt.. Three networks (MTN, Globalcom and Airtel) were considered to determine the cellular network with the best received signal strength using Radio Frequency Signal Tracker (RFST). The Radio Frequency Signal Tracker is an Application installed in a Techno Y4 mobile device which measures and displays the generated signal strength for each of the cellular network operators. The measurements of the signal strength for each of the mobile networks at the strategic location were recorded on daily basis. Measurements were conducted in the months of March 2017, April 2017 and May 2017 at each of the locations under consideration

The measurements were recorded at every distance of $100 \mathrm{~m}$ for a given route of $2000 \mathrm{~m}$. A total of twenty seven 
thousand six hundred $(27,600)$ Signal Strength data were recorded for the three cellular networks at the five locations. Table I, Table II and Table III shows the specification of the Base Transceiver Stations for the three cellular networks at the five locations.

The measurement tool employed for the measurement was a Techno Y4 with Radio Frequency Signal Tracker (RFST) version 1.3.2 installed in it. The software is an engineering application tool for performing hand-held drive test. It is basically used to monitor and record Signal Strength and Serving Cell Location (describing the cell site's zones of coverage) and save or play back the data. The software gives information such as Base Transceiver Station (BTS) over the air interface. It also identifies the network operators Mobile Network Code (MNC).

The software program is an engineering application for performing Ad-hoc drive tests. It allows for the monitoring and recording of Signal Strength and Serving Cell location as drive test is conducted.It displays the cell phone's number, the device phone type (None or GSM), the unique device ID, the serial number of the SIM card, the SIM state, software version, the unique subscriber identity and the current Signal Strength of the phone in $\mathrm{dBm}$. Network; here it gives the alphabetic name of the current registered operator, current network connection state, the radio technology currently being used, the Mobile Country Code as well as the Mobile Network Code used by the carrier, the Location Area Code and Cell ID, the current state of data traffic (IN, OUT, NONE, INOUT), the current data connection state, the current call state (Idle, Ringing or Off hook) and the number of neighbors being considered for selection as well as their individual Received Signal Strength Indicators (RSSI). Location; this service indicates weather you are using Google, Open Cell ID, or personal local site database to determine site location, displays current latitude and longitude in DMS (Degree Minutes and Seconds). The software program operates with the use of Geographic Position System. In course of the measurement, the Local Area Code, Cell Identity and Reception Transmission Level were constant while the Received Signal Strength in $\mathrm{dB} / \mathrm{m}$, Transmitting power and Reception Quality were changing. Mobile Country Code (MCC) and Mobile Network Code (MNC) were fixed for all networks. MCC for all networks is 621 , while MNC is 50 for Globalcom, 30 for MTN and 20 for Airtel as shown in the table below

\section{TABLE I: THE SPECIFICATION OF MTN BTS}

\begin{tabular}{|c|c|c|}
\hline Network & Locations & Specifications \\
\hline \multirow[t]{5}{*}{ MTN } & Borokiri & $\begin{array}{l}\text { Site No: T21472, Mcc: 621, } \\
\text { Mnc: 30, Lac: 10283, Cell ID: } \\
21479\end{array}$ \\
\hline & Old G.R.A & $\begin{array}{l}\text { Site No: T2098, Mnc: } 30 \text {, } \\
\text { Mcc: } 621 \text {, Lac: } 10283 \text {, Cell ID: } \\
16009\end{array}$ \\
\hline & RSU & $\begin{array}{l}\text { Site No: T188, Mnc:30, } \\
\text { Mcc:621, Lac:10283, Mcc: } \\
\text { 621, Cell ID: } 16279\end{array}$ \\
\hline & Ikwerre Road & $\begin{array}{l}\text { Site No: T0341, Mcc: 621, } \\
\text { MNC: } 30 \text {, } \\
\text { Lac: } 10283 \text {, Cell ID: } 3410\end{array}$ \\
\hline & Aba Road & $\begin{array}{l}\text { Site No: Nil, Mcc: 621, Mnc: } \\
\text { 30,Lac: } 60224 \text {, Cell ID: } 1313\end{array}$ \\
\hline
\end{tabular}

TABLE II: THE SPECIFICATION OF AIRTEL BTS

\begin{tabular}{lll}
\hline \hline Network & Locations & Specifications \\
\hline \hline AIRTEL & Borokiri & Site No: RV114, Mcc: 621, \\
& & Mnc:20, Lac: 453, Cell ID: \\
& 15542 \\
& Site No: RV121, Mnc: 20, Cell \\
& Old G.R.A & ID: 9321, Lac: 453, Mcc: 621 \\
& Site No: RV121, Mcc:621, \\
& Mnc:20, Lac:10283, Cell ID: & 7826 \\
& Site No: 2299, Mnc: 20, Mcc: \\
& 621, Lac:10283 Cell ID: 7826 \\
& Site No: RV0023, Mcc: 621, \\
& Lac: 538, Mnc: 20, Cell \\
& Aba Road & ID:40023 \\
\hline \hline
\end{tabular}

TABLE III: THE SPECIFICATION OF GLOBALCOM BTS

\begin{tabular}{lll}
\hline \hline Network & Locations & Specifications \\
\hline \hline GLOBAL & Borokiri & Site No: PAR028, Mcc: 621, \\
COM & & Mnc:50, Lac: 9500, Cell \\
& & ID:35281 \\
& Site No: Nil, Mnc:50, Mcc: 621, \\
& Lac: 9500, Cell ID: 36842 \\
& Site No: NC-00148, Mcc: 621, \\
& RSU & Mnc: 50, Cell ID: 35072 \\
& Site No: POT-002, Mcc: 621, \\
& Mnc: 50, Cell ID: 35072, \\
& Site No: Nil, Mnc: 50, Mcc: \\
& Aba Road & 621, Cell ID: 23109, Lac: 3040 \\
\hline \hline
\end{tabular}

B. Data Presentations

TABLE IV: AVERAGE MEASUREMENTS FOR BOROKIRI

\begin{tabular}{llll}
\hline \hline & MTN & Airtel & Globalcom \\
$\begin{array}{l}\text { DISTANCE } \\
(\mathrm{M})\end{array}$ & RSS $(\mathrm{dBm})$ & RSS $(\mathrm{dBm})$ & RSS $(\mathrm{dBm})$ \\
\hline \hline 200 & & & \\
400 & -55.9 & -55.3 & -59.1 \\
600 & -56.6 & -61.6 & -61.2 \\
800 & -58.0 & -62.9 & -63.3 \\
1000 & -60.3 & -63.8 & -65.5 \\
1200 & -58.7 & -66.0 & -66.6 \\
1400 & -63.2 & -67.9 & -69.2 \\
1600 & -64.6 & -69.8 & -69.9 \\
1800 & -66.3 & -73.5 & -73.3 \\
2000 & 70.8 & -77.3 & -77.0 \\
\hline \hline
\end{tabular}

TABLE V: AVERAGE MEASUREMENTS FOR OLD GRA

\begin{tabular}{llll}
\hline \hline $\begin{array}{l}\text { Distance } \\
(\mathrm{m})\end{array}$ & MTN & Airtel & $\begin{array}{l}\text { Globalcom } \\
\text { RSS }(\mathrm{dBm})\end{array}$ \\
\hline \hline 200 & RSS $(\mathrm{dBm})$ & RSS $(\mathrm{dBm})$ & -63.3 \\
400 & -57.2 & -59.7 & -65.2 \\
600 & -58.7 & -61.9 & -64.4 \\
800 & -60.7 & -64.8 & -68.5 \\
1000 & -61.7 & -65.9 & -71.4 \\
1200 & -62.5 & -67.5 & -71.9 \\
1400 & -65.5 & -70.4 & -73.0 \\
1600 & -66.8 & -73.5 & -75.5 \\
1800 & -68.9 & -75.3 & -79.9 \\
2000 & -70.9 & -77.8 & -82.8 \\
\hline \hline
\end{tabular}

TABLE VI: AVERAGE MEASUREMENTS FOR RSU

\begin{tabular}{llll}
\hline \hline $\begin{array}{l}\text { Distance } \\
(\mathrm{m})\end{array}$ & MTN & Airtel & Globalcom \\
& RSS $(\mathrm{dBm})$ & RSS $(\mathrm{dBm})$ & RSS $(\mathrm{dBm})$ \\
\hline \hline 200 & -62.6 & -57.5 & -59.2 \\
400 & -63.2 & -60.7 & -60.5
\end{tabular}




\begin{tabular}{llll}
600 & -64.8 & -68.8 & -62.6 \\
800 & -66.9 & -66.0 & -65.3 \\
1000 & -68.1 & -69.5 & -67.2 \\
1200 & -70.2 & -72.0 & -68.7 \\
1400 & -71.4 & -73.3 & -70.9 \\
1600 & -74.0 & -74.8 & -62.4 \\
1800 & -77.1 & -76.7 & -73.1 \\
2000 & -78.9 & -78.4 & -78.5 \\
\hline
\end{tabular}

TABLE VII: AVERAGE MEASUREMENTS FOR IKWERRE ROAD

\begin{tabular}{llll}
\hline $\begin{array}{l}\text { Distance } \\
(\mathrm{m})\end{array}$ & MTN & Airtel & Globalcom \\
\hline RSS $(\mathrm{dBm})$ & RSS(dBm) & RSS $(\mathrm{dBm})$ \\
\hline 200 & -59.0 & -59.6 & -60.3 \\
400 & -62.8 & -62.5 & -60.9 \\
600 & -64.3 & -63.8 & -64.2 \\
800 & -66.6 & -66.7 & -66.5 \\
1000 & -68.9 & -68.4 & -68.4 \\
1200 & -70.5 & -69.9 & -68.6 \\
1400 & -72.9 & -71.3 & -71.7 \\
1600 & -74.8 & -73.2 & -72.7 \\
1800 & -79.2 & -76.4 & -75.6 \\
2000 & -82.4 & -79.1 & -78.5 \\
\hline \hline
\end{tabular}

TABLE VIII: AVERAGE MEASUREMENTS FOR ABA ROAD

\begin{tabular}{llll}
\hline \hline $\begin{array}{l}\text { Distance } \\
(\mathrm{m})\end{array}$ & $\begin{array}{l}\text { MTN } \\
\text { RSS }(\mathrm{dBm})\end{array}$ & $\begin{array}{l}\text { Airtel } \\
\text { RSS }(\mathrm{dBm})\end{array}$ & $\begin{array}{l}\text { Globalcom } \\
\text { RSS }(\mathrm{dBm})\end{array}$ \\
\hline \hline 200 & -56.5 & -60.4 & -62.9 \\
400 & -59.1 & -61.4 & -64.4 \\
600 & -60.9 & -64.9 & -66.4 \\
800 & -63.3 & -66.8 & -67.3 \\
1000 & -66.4 & -70.9 & -69.2 \\
1200 & -68.5 & -72.9 & -70.6 \\
1400 & -69.7 & -74.8 & -71.8 \\
1600 & -72.5 & -76.8 & -73.8 \\
1800 & -73.9 & -79.5 & -72.5 \\
2000 & -77.4 & -81.7 & -80.3 \\
\hline \hline
\end{tabular}

TABLE IX: AVERAGE MEASUREMENT OF ALL THE NETWORK

\begin{tabular}{lll}
\hline \hline Location & Network & RSS $(\mathrm{dBm})$ \\
\hline \hline Borokiri & MTN & -61.9 \\
& Airtel & -67.3 \\
Old GRA & Globalcom & -65.5 \\
& MTN & -63.4 \\
& Airtel & -61.3 \\
RSU & Globalcom & -62.3 \\
& MTN & -68.6 \\
& Airtel & -70.1 \\
Ikwerre Road & Globalcom & -68.3 \\
& MTN & -69.7 \\
Aba Road & Airtel & -67.5 \\
& Globalcom & -64.9 \\
& MTN & -63.0 \\
& Airtel & -69.3 \\
\hline \hline
\end{tabular}

\section{RESULTS AND DISCUSSIONS}

\section{A. Signal strength Analysis}

To determine path loss for the conducted measurements at various distances free space propagation path loss model was used.

Path loss for free space is given as;

PL (d) $(\mathrm{dB})=32.45+20 \log (\mathrm{d})+20 \log (\mathrm{f}) \mathrm{dB}$

If frequency is given as $900 \mathrm{MHZ}$ and $\mathrm{d}$ is the distance between the transmitter and the receiver in $\mathrm{km}$

Considering free space log normal law

$\mathrm{PL}=20 \log \left(\frac{4 \pi d}{\lambda}\right)+10 \operatorname{nlog}\left(\frac{d}{d_{o}}\right)$

Where $\lambda$ is the wavelength, $\mathrm{C}$ is the speed of light and $\mathrm{f}$ is the frequency, while the operating frequency is $900 \mathrm{MHZ}$. Therefore $\lambda=\frac{3 \times 10^{8}}{900 \times 10^{6}}$

$\lambda=0.33$

For reference of $100 \mathrm{~m}$

$\mathrm{PL}=20 \log \left(\frac{4 \pi d}{\lambda}\right)$

$\mathrm{PL}=20 \log \left(\frac{4 \times 3.142 \times 100}{0.33}\right)$

$\mathrm{PL}=71.6 \mathrm{~dB}$

The path loss estimated from the measurement data with corresponding distance from the BTS for each of the networks were analyzed using Microsoft Excel. The path loss was observed to increase with corresponding increase in distance while conducting measurements as shown in Table $\mathrm{X}$. Path loss for the three networks is shown in figure 2, Figure 3 and Figure 4.

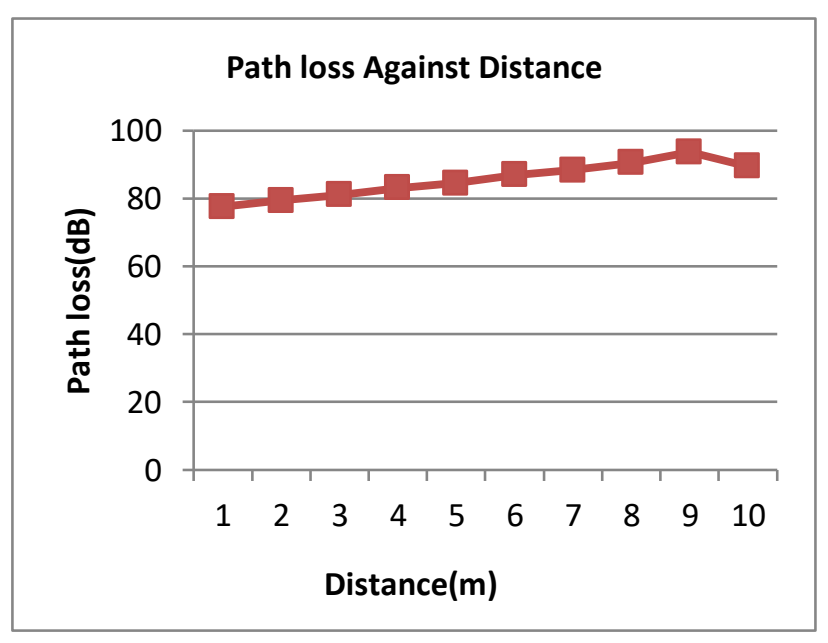

Fig.2. Path loss for MTN 
Figure 2 shows a plot of estimated average path $\operatorname{loss}(\mathrm{dB})$ against distance $(\mathrm{m})$ for MTN network at the selected locations. The plot showed that path loss increases with distance.

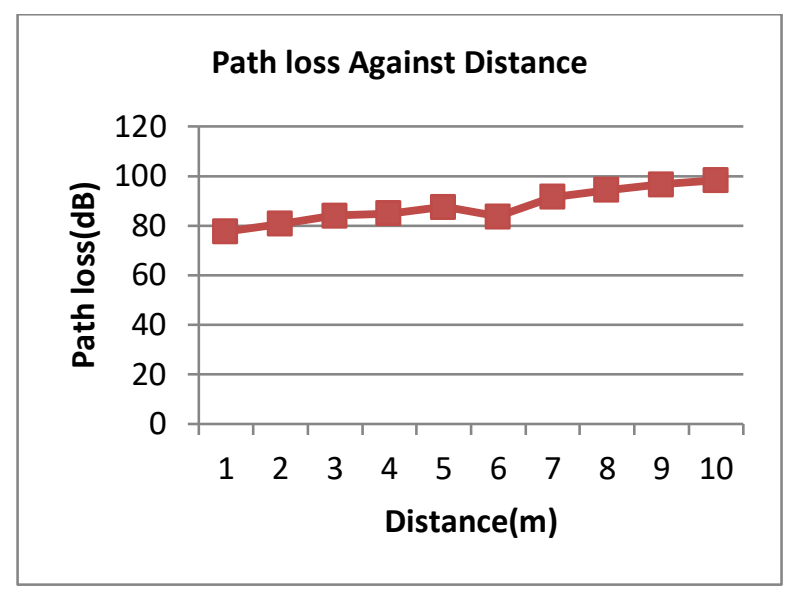

Fig. 3. Path loss for Airtel

Figure 3 shows a plot of estimated average path $\operatorname{loss}(\mathrm{dB})$ against distance $(\mathrm{m})$ for Airtel network at the selected locations. The plot showed that path loss increases with distance.

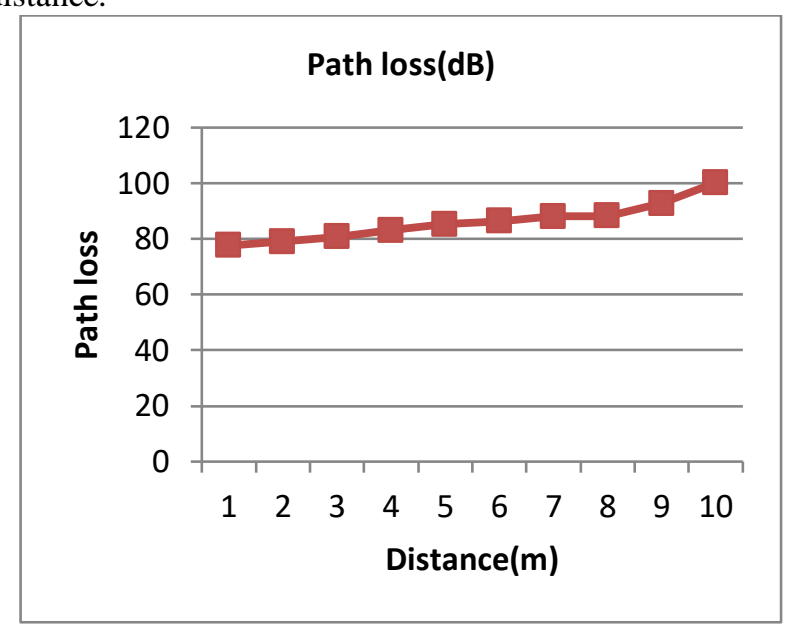

Fig. 4. Path loss for Globalcom

Figure 4 shows a plot of estimated average path $\operatorname{loss}(\mathrm{dB})$ against distance(m) for Globalcom network at the selected locations. The plot showed that path loss increases with distance.

\section{B. Model Development}

The measured data of the cellular networks at the five strategic locations based on the received signal strength were analyzed using Ordinary Least Square (OLS) regression in Microsoft Excel 2013. The results are shown in Tables X through XII for each network considered; a regression line was used to develop an equation as a developed model for predicting the path loss over distance. The table consist of the distance from the Base Transceiver Station to receiver (mobile device) while the coefficient of $\mathrm{x}$-variable are the slope of the regression line which is an indication of the rate at which the path loss increases with the distance from the BTS.
TABLE X: OLS REGRESSION RESULT FOR MTN

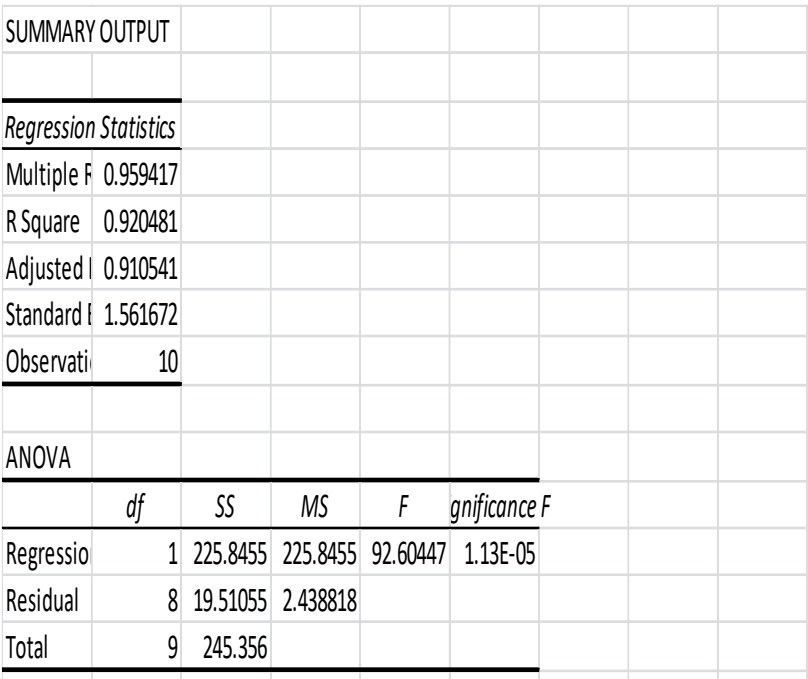

Coefficientiandard Err tStat P-value Lower 95\% Upper 95\% ower 95.0\% pper 95.0\% \begin{tabular}{lllllllll}
\hline Intercept & 76.38 & 1.066825 & 71.59564 & $1.61 \mathrm{E}-12$ & 73.9199 & 78.8401 & 73.9199 & 78.8401
\end{tabular} \begin{tabular}{llllllllll}
\hline XVariable 0.008273 & 0.00086 & 9.623121 & $1.13 \mathrm{E}-05$ & 0.00629 & 0.010255 & 0.00629 & 0.010255 \\
\hline
\end{tabular}

Table X shows the Ordinary Least Square Regression Analysis of the received signal strength of MTN network over distance. The analysis indicated that the correlation coefficient of the regression line is approximately 0.96 while the coefficient of determination $\left(R^{2}\right)$ is approximately 0.92 . The coefficient of distance ( $\mathrm{x}$-variables) is 0.0083 while the intercept is $76.38 \mathrm{~dB}$.

Hence, the developed path loss model equation for MTN is given as:

$\operatorname{PL}(\mathrm{dB})=76.38+0.0083 \mathrm{~d}$

TABLE XI: OLS REGRESSION RESULT FOR AIRTEL

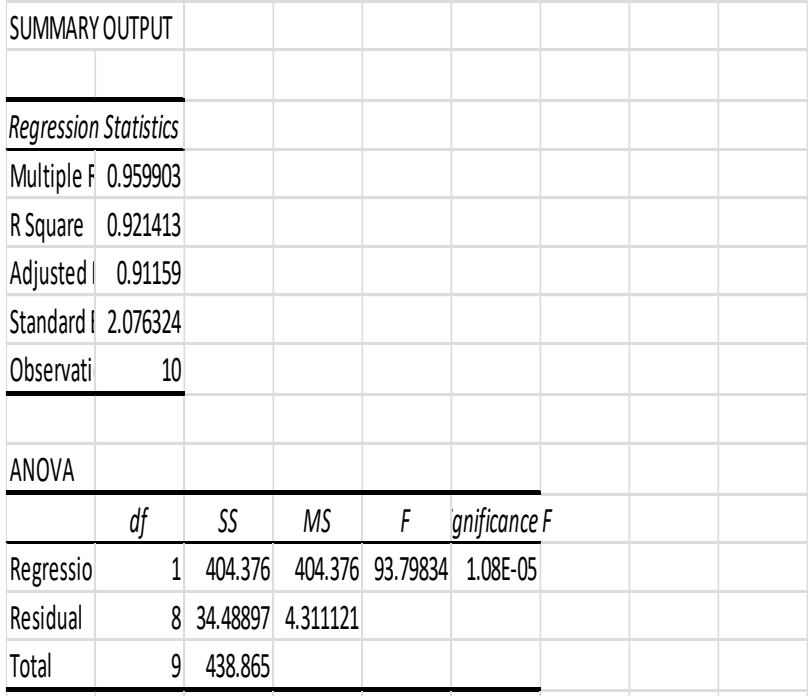

Coefficientandard Err tStat P-value Lower 95\% Upper 95\% ower 95.0\% pper 95.0\% \begin{tabular}{lllllllll}
\hline Intercept & 75.77333 & 1.418399 & 53.42172 & $1.67 E-11$ & 72.5025 & 79.04417 & 72.5025 & 79.04417
\end{tabular} $\begin{array}{llllllllll}\text { XVariable } & 0.01107 & 0.001143 & 9.684955 & 1.08 E-05 & 0.008434 & 0.013705 & 0.008434 & 0.013705\end{array}$

Table XI shows the Ordinary Least Square Regression Analysis of the received signal strength of Airtel network over distance. The analysis indicated that the correlation 
coefficient of the regression line is approximately 0.96 while the coefficient of determination $\left(R^{2}\right)$ is approximately 0.92 . The coefficient of distance ( $\mathrm{x}$-variables) is 0.0111 while the intercept is $75.77 \mathrm{~dB}$.

Hence, the developed path loss model equation for Airtel is given as:

$\mathrm{PL}(\mathrm{dB})=75.77+0.0111 \mathrm{~d}$

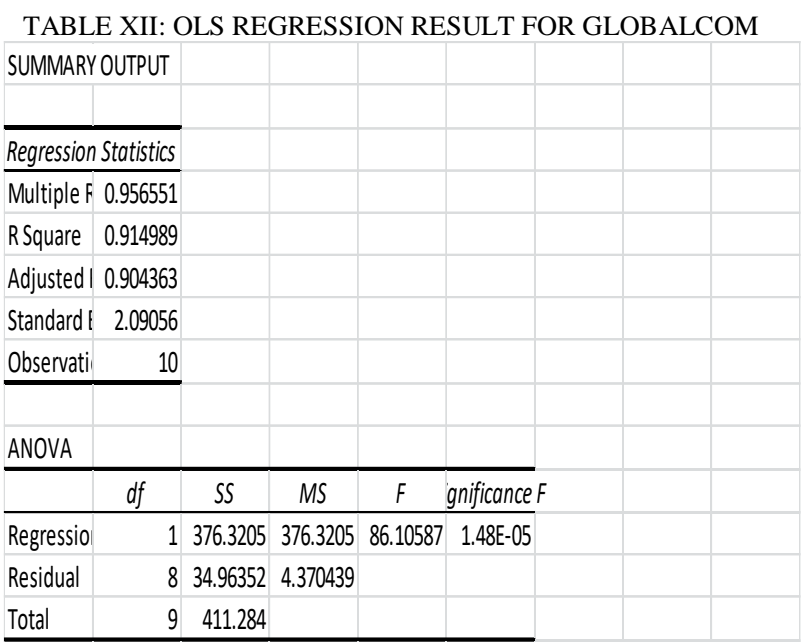

Coefficientandard Err tStat P-value Lower 95\%'Jpper 95\%

\begin{tabular}{l|lllllllll} 
Intercept & 74.39333 & 1.428124 & 52.09165 & $2.04 E-11$ & 71.10007 & 77.68659 & 71.10007 & 77.68659
\end{tabular} \begin{tabular}{lllllllll} 
XVariable 0.010679 & 0.001151 & 9.279325 & $1.48 \mathrm{E}-05$ & 0.008025 & 0.013333 & 0.008025 & 0.013333 \\
\hline
\end{tabular}

Table XII shows the Ordinary Least Square Regression Analysis of the received signal strength of Globalcom network over distance. The analysis indicated that the correlation coefficient of the regression line is approximately 0.96 while the coefficient of determination $\left(R^{2}\right)$ is approximately 0.91 . The coefficient of distance (x-variables) is 0.0115 while the intercept is $74.39 \mathrm{~dB}$.

Hence, the developed path loss model equation for Globalcom is given as:

$\mathrm{PL}(\mathrm{dB})=74.39+0.0115 \mathrm{~d}$

Where $\mathrm{d}$ is the distance between the transmitter and the receiver in meters.

\section{CONCLUSION}

The Paper showed that as the mobile equipment (receiver) was moved away from the Base Transceiver Station the signal strength was observed to be reduced. In all the measurements, the results were analyzed to determine the path loss propagation model shown in equations (19), (20) and (21). This work has informed subscribers the network choice to use at various locations Port Harcourt in order to reduce the challenge of network failure or lack of signal for effective communication. In this research it has been established that transmitted signals gets weak as they are propagated through the air space, building and other physical obstructions. Also path loss increases with measurement distance from the BTS.

\section{REFERENCES}

[1] J. I. Wojuade (December, 2003), Impact of Global System for Mobile Telecommunication in Nigerian Economy: A Case of Some Selected Local areas in Oyo State, Nigeria.

[2] A. Mitra, Mobile Communication, Department of Electronics and Communication Engineering, Indian Institute of Technology, Guwahati, India, PP. 24-29.

[3] A. I. Idim and F. I. Anyasi, (2014) Determination of Building Penetration Loss of GSM Signals, vol. 9, PP. 1-5.

[4] B.I.Bakare, I.A Ekanem and I.O. Allen (June, 2017). Appraisal of Global System for Mobile Communication in Nigeria, American Journal of Engineering Research.[Online]. 6(6), pp. 97-102. Available: http://ajer.org/papers/v6(06)/N060697102.pdf

[5] T. S. Rapport, Wireless Communications, Principle and Practice Upper Saddle River NJ Prentice Hall (2002), PP. 75-92.

[6] A. A. Nwankoro and K. C. Emerole. (April, 2015). A Case Study of Propagation Path- Loss Models, American Journal of Engineering Research. Vol.4, PP. 11

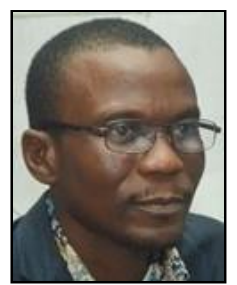

B. I. Bakare holds a Bachelor of Engineering (B.Eng.) Degree in Electrical Engineering; $\mathbf{2}^{\mathbf{1}}$ from Ondo State University, Ado Ekiti, ( Now University of Ado Ekiti, Ekiti State), Master of Engineering (M.Eng.) Degree in Electrical/Electronic Engineering from University of Port Harcourt, Nigeria and he is currently a PhD (Communication Engineering) Researcher of Nnamdi Azikiwe University (Unizik), Awka, Anambra State. He holds a Category One Electrical Wiring License. He is a COREN registered Engineer, a Corporate Member of Nigeria Society of Engineers (NSE), a member of International Association of Engineers (I A ENG) and an active member of Nigeria Institute of Electrical and Electronics Engineers (NIEEE). He is presently a lecturer in the Department of Electrical Engineering, Rivers State University, Port Harcourt., Nigeria. He is married with children.

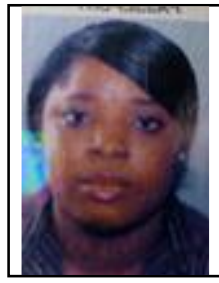

T. E. Ngeri holds a Bachelor of Technology (B.Tech) degree in Electrical Engineering (Electronics option) from the Rivers State University of Science and Technology (now Rivers State University) and she is currently an M.Tech (Communication Engineering Option) Researcher of the Rivers State University, Nkpolu Oruworukwo, Rivers State. She is presently an Electrical Instructor in the Department of Electrical Engineering, Government Technical College Ele-Ogu, Ogu/Bolo, Rivers State

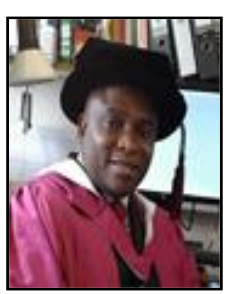

Sunny Orike received his B. Tech. in Computer Engineering from Rivers State University of Science and Technology (now Rivers State University); M.Sc. in Computing and M.Phil. in Computational Intelligence, both from Robert Gordon University, Aberdeen, United Kingdom; and Ph.D in Artificial Intelligence from HeriotWatt University, Edinburgh, United Kingdom.

Dr. Orike is an active member of several professional bodies, including Council for the Regulation of Engineering in Nigeria, Nigeria Institution of Electrical Electronic Engineers and International Association of Engineers. He is a Senior Lecturer and former Head, Department of Electrical \& Computer Engineering, Rivers State University, Port Harcourt, Nigeria.

Dr. Orike has published in several reputable journals, presented at both local and international conferences, and acts as a reviewer to several journals. He is a Facilitator with the National Open University of Nigeria, and External Assessor for Port Harcourt Polytechnic, Nigeria. He is married with children, and can be reached on: orike.sunny@ust.edu.ng. 